\title{
Community-building through collaborative peer-generated formative assessment: enhancing attainment and assessment literacy
}

\author{
Emma Roberts \\ University of Chester, UK
}

Keywords: peer assessment; community; collaboration; co-creation; formative; Covid-19.

\section{The challenge}

Learning under Covid-19 conditions, with much of the teaching occurring online, increased student time online. This had the positive effect of creating an active learning community for a frontloaded, intense six-week undergraduate law module. A downside to this, however, was that greater time spent on the virtual learning platform fundamentally altered the way online resources were used by the students, essentially increasing their engagement with such resources, thus exhausting their value far sooner. This paper describes the initiative designed to overcome the challenge posed by changes in student study behaviour in respect of a multiple-choice test (MCT) assessment.

To help prepare students on a core first-year undergraduate Law module for the summative MCT assessment, a formative MCT was introduced on the module's virtual learning environment on a weekly-release basis. The MCT assessed the students' knowledge of the foundations of the legal system. Formative assessment took on greater importance given the intense delivery schedule, since the module introduced students to their first university assessment (Şenel and Şenel, 2021). As students grew more accustomed to balancing their time across all the module's learning activities, the number of questions set increased and all questions were amalgamated to create a time-limited replica of the summative assessment by the penultimate week of the module's delivery. Very engaged students would retake the formative assessment several times. By the end of the module's penultimate week, learners were engaging with the tool but, by the third formative attempt, few questions were being answered incorrectly. The tool was proving its 
value in generating learning gain and in familiarising the students with the digital skills needed to engage with the tool that was to be used for the summative assessment. Its value in testing knowledge, however, had (for some) plateaued. Students evidently felt the value of the formative assessment tool was limited by the fact that they were simply being re-presented with the same questions that they had already responded to during the module's delivery (McCallum and Milner, 2021).

When learning had primarily been classroom-based, the use of the formative MCT tool was predominantly used during classroom teaching when prompted by the instructor. However, adopting blended learning meant greater use of this online resource which highlighted some of its limitations. The closed nature of the resource meant more students experienced a plateau and it was felt that students would benefit from greater exposure to formative assessment. To achieve this end, more questions would need to be designed but staff lacked time to do so, given the intense delivery of the module's teaching: this further compounded the challenge.

\section{The response}

Students were offered an opportunity to create a bank of multiple-choice questions. By this point in the module's delivery, the group had created a strong learning community. They were demonstrating strong team-working ability through peer-support and social presence (Peacock et al., 2020), interacting daily on the chat thread, resolving uncertainties and sharing knowledge. Inspired by the students' enthusiasm for learning and seeking to capitalise and extend upon the strong community spirit, offering this opportunity helped formalise their peer-to-peer support, whilst at the same time providing individuals an opportunity to test their own knowledge and understanding of the assessment material by engaging in assessment-creation.

Students were asked to devise a question and produce four possible answers. This initiative was facilitated by a shared spreadsheet document. Students' understanding of the necessary format had been established through their use of the existing formative Quiz tool. Students were asked to contribute by the end of the week, so that the instructor could moderate the submissions for accuracy and produce a finished tool to replicate the existing formative assessment. Participation was entirely optional and the ultimate product 
of this exercise was accessible by the entire cohort. Not all students were at the stage of seeking out further formative assessment as the self-paced nature of some of the module's delivery meant that some students had not yet attempted the existing formative assessment tool.

The community-driven project stimulated immediate enthusiasm across the group. The time limitation may have prevented some from contributing but $43 \%(n=47)$ of the cohort took up the opportunity. With a total cohort of 110 students and the number of attempts on the peer-generated assessment tool totalling 137, a significant proportion, if not all, students used it and many used it more than once. The tool not only replicated the benefit of the existing formative assessment tool across a greater range of subject areas, but it also supported learning (Sekendiz, 2018) and further enhanced the module's learning community, which prepared students well for teamworking and peer-to-peer learning and assessment in their subsequent modules (Hogg, 2018).

The initiative aligned with the instructor's social constructivist ethos (Vygotsky, 1978), at the core of which is the principle that students have as much as the instructor to contribute to one another's learning, and the belief that students need to be empowered to take responsibility for their own learning (Boud, Cohen and Sampson, 1999). 17\% $(n=18)$ of the cohort engaged in an enhanced evaluation of the module's provision, wherein students spoke strongly of the module's capacity to prepare them for future learning opportunities (see Figure 1).

Figure 1. Enhanced module evaluation survey results.

\begin{tabular}{|l|c|}
\hline \multicolumn{1}{|c|}{ Evaluation statement } & $\begin{array}{c}\text { Percentage of students who } \\
\text { agreed or strongly agreed with } \\
\text { the statement }\end{array}$ \\
\hline $\begin{array}{l}\text { The module prepared us well for learning from peers } \\
\text { within the virtual learning community }\end{array}$ & $78 \%$ \\
\hline The module prepared us suitably for the MCT & $89 \%$ \\
\hline $\begin{array}{l}\text { Everyone stood a fair chance of performing well on } \\
\text { the test }\end{array}$ & $94 \%$ \\
\hline $\begin{array}{l}\text { I would like to see more of this form of assessment } \\
\text { preparation and method of assessment on other } \\
\text { modules }\end{array}$ & $94 \%$ \\
\hline
\end{tabular}

The summative assessment yielded a $100 \%$ pass rate with marks ranging from $42 \%$ to $97 \%$ and an average mark of $78 \%$. 


\section{Recommendations}

Students are assessment-driven (Rust, 2005) and formative assessment opportunities increase confidence levels ahead of summative assessment opportunities (Leenknecht et al., 2021). Peer-generated assessments foster strong community-building across a cohort (Boud, Cohen and Sampson, 1999) which can enhance student preparedness for future learning opportunities and attainment. This initiative enhanced the students' assessment literacy by engaging them in the design of the assessment, meaning they worked through the same considerations as the instructor did in creating formative assessment. Moreover, working together to create an assessment tool helped create a strong online learning community (Peacock et al., 2020), whereby their investment of time and effort into the task of creating a bank of questions benefitted the cohort as a whole.

This model can be implemented on other modules by seeking out opportunities for students to engage in assessment design and to test their own ability to reach the module's learning outcomes by replicating the module's summative assessment. Allowing unlimited attempts on formative assessment built the students' resilience to the constraints of time and task management. Furthermore, students actively reflected upon and shared their reflections on the assessment process with one another and with the instructor on an online learning platform, thus, safeguarding assessment for learning and allowing the instructor insight into ways in which the tool could be further developed.

\section{References}

Boud, D., Cohen, R. and Sampson, J. (1999) 'Peer learning and assessment', Assessment \& Evaluation in Higher Education, 24(4), pp.413-426. https://doi.org/10.1080/0260293990240405.

Hogg, L. M. (2018) 'Empowering students through peer assessment: interrogating complexities and challenges', Reflective Practice, 19(3), pp.308-321. https://doi.org/10.1080/14623943.2018.1437404. 
Leenknecht, M., Wijnia, L., Köhlen, M., Fryer, L., Rikers, R. and Loyens, S. (2021)

'Formative assessment as practice: the role of students' motivation', Assessment \& Evaluation in Higher Education, 46(2), pp.236-255.

https://doi.org/10.1080/02602938.2020.1765228.

McCallum, S. and Milner, M. M. (2021) 'The effectiveness of formative assessment: student views and staff reflections', Assessment \& Evaluation in Higher Education, 46(1), pp.1-16. https://doi.org/10.1080/02602938.2020.1754761.

Peacock, S., Cowan, J., Irvine, L. and Williams, J. (2020) 'An exploration into the importance of a sense of belonging for online learners', The International Review of Research in Open and Distributed Learning, 21(2), pp.18-35. https://doi.org/10.19173/irrodl.v20i5.4539.

Rust, C. (2005) 'Developing a variety of assessment methods', in Quality Assurance Agency for Higher Education, 2005, Reflections on Assessment. Vol. 1. Mansfield: Quality Assurance Agency for Higher Education, Enhancement themes publications, pp. 179-186. Available at: https://www.enhancementthemes.ac.uk/docs/ethemes/assessment/reflections-onassessment-volume-i.pdf (Accessed: 30 September 2021).

Sekendiz, B. (2018) 'Utilisation of formative peer-assessment in distance online education: a case study of a multi-model sport management unit', Interactive Learning Environments, 26(5), pp.682-694. https://doi.org/10.1080/10494820.2017.1396229.

Şenel, S. and Şenel, H. C. (2021) 'Remote assessment in higher education during COVID19 pandemic', International Journal of Assessment Tools in Education, pp.181-199. https://doi.org/10.21449/ijate.820140.

Vygotsky, L. S. (1978) Mind in society: the development of higher psychological processes. Cambridge, MA: Harvard University Press.

\section{Author details}


Emma Roberts is an Associate Professor in Legal Studies and Director of Transition, Learning and Teaching at the University of Chester's Law School. She has led on numerous projects relating to assessment and feedback. Most recently, she undertook empirical research into moderation and standardisation praxis in the context of undergraduate Law programmes. She is a Senior Fellow of the Higher Education Academy, is an invited speaker at institutions which run Senior Fellow programmes and a mentor to applicants pursuing this end. She is also an active researcher in Private International Law, the subject of her PhD. 